The Heights of the Central African Lakes and Mountains

Author(s): T. T. Behrens

Source: The Geographical Journal, Vol. 30, No. 2 (Aug., 1907), p. 219

Published by: geographicalj

Stable URL: http://www.jstor.org/stable/1776642

Accessed: 20-06-2016 22:09 UTC

Your use of the JSTOR archive indicates your acceptance of the Terms \& Conditions of Use, available at

http://about.jstor.org/terms

JSTOR is a not-for-profit service that helps scholars, researchers, and students discover, use, and build upon a wide range of content in a trusted digital archive. We use information technology and tools to increase productivity and facilitate new forms of scholarship. For more information about JSTOR, please contact support@jstor.org.

The Royal Geographical Society (with the Institute of British Geographers), Wiley are collaborating with JSTOR to digitize, preserve and extend access to The Geographical Journal 


\section{The Heights of the Central African Lakes and Mountains.}

Since the publication of the article in the Journal of March, 1907, I have received a communication from Mr. R. E. Allen, Director of Surveys, Uganda Protectorate, in which he says that a line of levels has been run from Lake Victoria at Entebbe to Lake Albert at Butiaba, and that the difference between the two was found to be 1692 feet.

This is the result of levelling one way only, so there has been no check on the figures. Nevertheless, we must now regard the height thus determined as the most reliable value for Lake Albert (2028 feet above M.S.L.).

The height published in the Journal was 1937 feet, obtained by an aneroid difference between Lake Albert Edward and Lake Albert.

Dr. Kohlschütter has kindly taken the trouble to send some remarks on the heights published in the same article. He considers that the probable error assigned to the difference in height between Muhavura and Lake Tanganyika is far too small, for the following reasons :-

1. He does not think Muhavura's apex is sufficiently well defined to ensure the same point being taken as the highest from every direction.

2. The probable error of the Kivu triangulation should be greater, as it was of a rapid order, and the coefficient of refraction which was used has never been stated.

He does not think it possible, judging by the results of the whole of his barometric determinations in East Africa, that his height could differ from any determination, with a p.e. of \pm 13 feet, by as much as 58 feet.

The mean error of a single barometric determination after elimination of the climatic factors by his method is \pm 33 feet, and the barometric height of Tanganyika given is the result of eight months' continuous observations.

T. T. Behrens.

\section{The Dar Homr.}

Daglingworth House, Cirencester, July 2, 1907.

The copy of the Journal for June, 1907, has just reached me from Egypt; in it I notice some notes on Dar Homr by Captain W. Lloyd (p. 649), and send you the following remarks :-

1. The southern boundary is Bahr el Arab and the river Kir.

NoтE.-The Bahr el Arab is the river Kir, and takes this name "Kir" when it enters the Dinka country either before or after joining with the rivers that join the river Lol below Sultan Robs.

2. On the map in two places it is entered, "To Dar Jange."

Note.-Does this convey anything to any one who studies the map? I presume not. Dar Jange = to Dinka country. The Dinkas are called by the Arabicspeaking races Jange, or in the western part of the Bahr al Ghazal it is more correct to say "Junge."

3. "Liang are numerous."

Note.-Am I mistaken in this word? I have never yet heard of such a beast. Should it not be "Tiang," a sort of hartebeest very common in the Bahr el Ghazal and on the lower reaches of the Bahr el Arab?

$$
\begin{aligned}
& \text { C. Percival, } \\
& \text { Captain, Rifle Brigade. }
\end{aligned}
$$

